Artículo

\title{
El país donde no pasa(ba)nada
}

\section{The country where nothing happens(ed)}

Pablo Oyarzun R. *

*UNIVERSIDAD DE CHILE

\section{Resumen:}

Este artículo propone de figura de la evasión como acontecimiento que desafía los marcos normales de comprensión para dar cuenta de la irrupción de movilizaciones que en Chile hemos llamado "revueltas" o "estallido". Esta lectura de la evasión se enfoca en registrar la reconfiguración de tres categorías que atraviesan el momento actual: la de "pueblo" como espectro y promesa de asamblea; la de "imagen" como modo de ser y como espacio y tiempo del encuentro; y la de "violencia" como factor estructurante de la democracia, así como evidencia de un (su) vacío y necesidad de traducción.

Palabras clave: Evasión; Acontecimiento; Pueblo; Imagen; Violencia.

\begin{abstract}
:
The article offers the figure of evasion as an event that challenges normal frameworks to come to terms with the irruption of social mobilizations that have been called "revolts" or "bursting" (estallido). This reading of evasion focuses on the registering of the reconfiguration of three categories crisscrossing the current moment: that of "people" (pueblo) as specter and promise of assembly; that of "image" as way of being and as space and time of encounter; and that of "violence" as structuring factor of democracy, as well as an evidence of a (its) void and need for translation.
\end{abstract}

Keywords: Evasion; Event; People; Image; Violence. 
Recibido: 5 de abril de 2020

Aceptado: 5 de mayo de 2020

Nadie en Chile ha estado exento de decir o de confesar, más bien, cuán imprevisible era el estallido social que se inició el 18 de octubre, estimulado por la "movilización secundaria" (de estudiantes de enseñanza media) que llamó a evadir el pago del metro de Santiago, gravado con una cuarta alza en dos años.

Diversas voces han ofrecido sus hipótesis y diagnósticos. Algunas de ellas se han caracterizado por contar con interpretaciones generales, asentadas sobre premisas a las que ellas mismas conceden indiscutido crédito. Sin embargo, tengo la impresión de que esas son las que más lejos están de entender lo que ha pasado y sigue pasando. Hay un rasgo que, creo, las caracteriza a todas, que las caracteriza por más o por menos, pero es un rasgo común. Sea su combustible el malestar, la arrogancia o la euforia, ellas coinciden en leer el acontecimiento con lo que ya saben. Dicho de otro modo, aplican al acontecimiento una plantilla conceptual previamente asegurada.

Empleo la palabra "acontecimiento" a propósito, no porque quiera cargarla, como de contrabando, con densidades teóricas, sino porque eso que llamamos así tiene la virtud, es decir, la fuerza de desconcertar los marcos en que estamos acostumbrados a encuadrar lo que pasa. No hablo solo de lo que, diríamos, es un acontecimiento con posible alcance histórico. Me refiero a todo tipo de acontecimiento, es decir, a la contingencia como modo y ritmo de lo que pasa, que siempre tiene, por pequeña o discreta que sea, una fuerza que obliga a pensar, a tratar de entender, a entender y hacer u omitir algo al respecto. Las más de las veces el acontecimiento puede ser alojado al interior de algún marco que tenemos predispuesto. El punto es que el acontecimiento de que hablamos aquí ofrece resistencia mayor a esa integración.

En filosofía - pero ciertamente no solo en ella sino, en principio, en todo intento de conocimiento y comprensión- se debería estar habituado, o al menos avisado, de que un determinado hecho o una determinada circunstancia que ofrece resistencia a los esquemas a los que usualmente recurrimos bien puede sugerir que se haga una revisión cabal de los mismos. Hablemos de momento aporético, de duda, de crítica, lo que se quiera; en general 
se trata de suspender la inercia de esos esquemas, de hacer un poco de tabla rasa, por decirlo de algún modo. El primer paso es confesarse a sí mismo que no se está entendiendo lo que pasa.

No entenderlo no es un cierre: es el comienzo de una apertura. $\mathrm{Y}$ es preciso ser paciente para que sea posible advertir paulatinamente los rasgos del acontecimiento, en sí inestables y por eso mismo indicadores de un haz diverso de líneas de fuga, solo algunas de las cuales podrían ser convergentes. Se trata de percibir y pensar.

Ante todo: atender a lo que pasa. De la manera más simple, más llana y contundente, creo que lo que las movilizaciones, manifestaciones y demandas que se han sucedido incesantemente en el último tiempo en Chile se concentran en algo así como una inferencia colectiva lógicamente impecable: permanentemente sufrimos abuso; hay que cambiar las reglas del juego. Ese es el sentido que tiene la demanda abrumadora de una nueva constitución (y el proceso constituyente en que se encuentra el país) decidida por el pueblo, y también la exigencia de medidas específicas de máxima urgencia, que permitan compensar el duro gravamen que el abuso impone sobre tantas vidas, empujándolas al límite de la subsistencia.

Abuso: se debe a la movilización feminista -la marcha y concentración de 400 mil mujeres el 8 de marzo de 2019 dejó en claro las cosas- que se haya empezado a entender lo que la palabra dice, lo que implica, las múltiples estribaciones a través de las cuales se expande hasta alcanzar los recodos más improbables de la vida; cómo es que esa palabra nombra la miseria de esa vida, no de la que resiste, aun en su destrozo, sino la miseria que le es impuesta. Cambiar las reglas, rediseñar el campo de los conflictos, de los intereses y las demandas: eso ya estaba meridianamente implicado en la movilización. Quizá porque eran las mujeres sus agentes, no se la supo leer en todo su alcance.

Pero no se trata solo de esa inferencia que me parece reconocer en el nervio de la revuelta social. Es también, en toda su envergadura, la multiplicidad de formas que esta ha asumido y sigue asumiendo. Sobre eso hay que clavar la atención.

\section{"Pueblo"}


Todo está registrado: tomas, trechos, momentos, eventos, instantáneas. Todo: los múltiples destellos y esquirlas del “estallido social”. Del Suceso: escribiré por única vez con mayúscula esta palabra, solo para indicar su fuerza, la peculiar unidad plural (y la singularidad repartida) de su movimiento. Me interesa interrogar esa unidad plural y la repartida singularidad que creo ver en ella

Sin perjuicio del esfuerzo orientado a la disminución de la pobreza y a la recuperación (parcial) de derechos sociales, durante todo el periodo de la transición se mantuvieron intactos los dispositivos nucleares de las bases neoliberales impuestas por la dictadura. No se trató solamente de los marcos normativos, fuertemente respaldados por la hipoteca representada por lo que en su momento se llamó los "poderes fácticos"1, dotados de la suficiente fuerza para incidir en toda decisión relevante para el país, sino que se trató y se trata de la reproducción sistemática de la determinación de todas dimensiones de la vida social por la dinámica de un mercado desprovisto de regulaciones que permitiesen proteger (para no decir incrementar) aquellos derechos sociales.

El efecto mayor fue el crecimiento significativo de la clase media. Se supone que una expansión de la clase media, con la incorporación de sectores que pudieron salir de condiciones socioeconómicas precarias o de pobreza, debe dar una mayor estabilidad a la sociedad, porque los sectores que han alcanzado un mínimo nivel de bienestar tienden a adherir al sistema de vida vigente y a no simpatizar con cambios mayores del mismo, porque estos podrían afectar precisamente ese bienestar, por exiguo que sea. En ese sentido, visto desde el punto de vista del sistema, dicha expansión es un insumo de su misma reproducción y perpetuación. Sin embargo, en el caso chileno, el logro de estos mínimos estándares de bienestar se alcanzó sobre la base del endeudamiento. Solo fue posible acceder a bienes y servicios (salud, educación, vivienda, mobiliario y equipamiento doméstico, vehículo, etcétera) contrayendo compromisos económicos a largo plazo que muy pronto evidenciaron ser demasiado onerosos para la disponibilidad de recursos, mayormente destinados a las necesidades básicas. Se sumó a esto el agravante de una previsión fundada en la

\footnotetext{
${ }^{1}$ La expresión fue trasladada desde otras regiones a Chile por Andrés Allamand, en los 90, en referencia al empresariado, el ejército, la iglesia católica (enumerados en orden de importancia), no tanto (se diría) como la denuncia de las hipotecas (vuelvo a emplear el término) impuestas a la menos que párvula democracia a la sazón, sino, en buenas cuentas, como reclamo por el peso que aquellos poderes tenían y tienen sobre la política de derechas. Hoy el senador Allamand, sin acusar ni mencionar esos poderes, actúa desde la institución del parlamento con un libreto digno de la más cruda facticidad.
} 
capitalización individual que, en virtud de sus condiciones y restricciones, dejó en el desamparo a las personas de la tercera y cuarta edades, con jubilaciones miserables que están por debajo de la línea de la pobreza.

Como consecuencia, extensos sectores medios que deberían ser garantes de la estabilidad del sistema se han visto forzados a vivir en condiciones de miedo cotidianizado debido a la amenaza constante de carecer de lo suficiente para pasar de un mes a otro y poder, al mismo tiempo, solventar el cúmulo de deudas e intereses. Es un nuevo tipo de miedo, cabe decir, no menos sensible que aquel otro, intenso, corrosivo, lacerante, que imperaba en los tiempos de la dictadura: precisamente como si (o porque) el combustible principal del sistema fuese (es) el miedo. De hecho, el sistema (o el modelo, como quiera que se lo llame, no hago asunto de eso ahora) funciona en un círculo clausurado de miedo y seguridad. La necesidad de seguridad se nutre del miedo, la incertidumbre, la amenaza: es razón de que la delincuencia, sin importar si las estadísticas puedan evidenciar decrecimiento, se convierta en un factor cardinal del discurso de derechas. Se requiere que la población sienta al menos vagamente la carcoma del miedo para que la ansiedad de mantenerse seguros sea un resorte psicosocial internalizado: entonces el discurso aquel campea, no sin que todos los medios que sus emisores tienen en su control lo refuercen día a día.

Pero, quizá, distinto es si ese miedo, ya no genéricamente, como amenaza exterior, sino constantemente se percibe, se padece, incide de manera sorda, latente y con evidencias de que solo puede agravarse cada día, semana o mes. Este es, podría decirse, el punto crítico hobbesiano: hay un umbral de miedo que, de ser excedido, hace imposible atender a la voz de la razón y ponderar los artículos de paz que propone ${ }^{2}$. Traspasado ese umbral, lo único posible, como signo de vida (es decir, de sobrevivencia) es la rebelión, la violencia. No la violencia como opuesto de la razón, sino como la única razón restante. "Nos quitaron tanto que hasta nos quitaron el miedo" es uno de los lemas reiterados del "estallido".

Ocurrió lo que se suele llamar "la gota que derramó el vaso": un aumento marginal de 30 pesos en el costo del billete de metro que, al cambio del día en que comienza el “estallido”, representaba no más de US\$ 0,04, si bien en el metro más caro de América Latina.

\footnotetext{
${ }^{2}$ Es precisamente la lección de Leviathan: si bien Hobbes defiende la soberanía absoluta y condena las rebeliones ideológicamente motivadas, admite la rebelión que nace de la necesidad, es decir, cuando el Estado amenaza la mera vida de los súbditos. Ver Thomas Hobbes, Leviatán. O la materia, forma y poder de una república eclesiástica y civil (Ciudad de México: Editorial Fondo de Cultura Económica, 2017).
} 
Estudiantes de la educación secundaria -que ya en 2006 habían impulsado la mayor movilización de la historia del país en ese nivel formativo, la "revolución pingüina" por el derecho a la educación - inician una campaña de acciones con el llamado “evade”. El llamado tiene un efecto que se amplía multitudinariamente: saltar por sobre los torniquetes que se accionan con el billete de metro, burlarlos de una u otra manera, se convierte en un deporte subterráneo masivo. El llamado y las consiguientes acciones sobrepasan con creces el efecto que alcanzó en 2011 la demanda por una “educación gratuita, pública y de calidad”. No es difícil entender por qué, una vez que las cosas están a la vista. La gratuidad era, precisamente, una demanda: tiene fuera de sí misma al agente que puede y en principio debe satisfacer la demanda: el Estado y sus poderes. Digamos que, aun siendo aquella una fuerza que llegó a poner en entredicho al gobierno se mantiene al interior del marco establecido, reconociéndolo como el límite de su acción.

En "evade" no hay demanda, hay ejecución. Es poder ejecutivo.

En 2011, por cierto, la estructura y performatividad de la manifestación cambió (sin perder el sentido reivindicativo), asumiendo por una parte notas de carnaval, y por otra enriqueciendo su carácter con la diversificación de los mensajes y la creatividad artística. Es verosímil pensar que este cambio contribuyó a la adhesión ciudadana al movimiento y sus demandas (que, como se recordará, alcanzó en su peak a más del 80\%).

Pero lo más decisivo del movimiento consistió en la transformación del sentido común. Y un cambio del sentido común es de las mayores consecuencias en términos sociopolíticos (evoco a Gramsci). Solo unos pocos meses antes del comienzo de las movilizaciones a fines de abril de 2011, casi nadie habría prestado oídos a quien postulase la gratuidad en la educación universitaria. Por mucho que se considerase excesivamente oneroso su costo, que en muchos casos hubiese evidencia de que este no guardaba relación alguna con la calidad ofrecida, y que la idea de una educación pública pagada, provista por el Estado, pudiera sonar, si no contradictoria, al menos equívoca, existía una naturalización del credo neoliberal de los bienes de consumo (el concepto fue invocado por el presidente Piñera en medio de la crisis): es obvio -decían los defensores del esquema- que si la educación universitaria le asegura (suponiendo que sea así) un retorno económico importante a su egresado, este debe pagar por su formación y saldar la deuda, en caso que haya debido 
contraerla (lo que es mayoritario), a la medida de los ingresos de los que se haya hecho beneficiario en virtud de esa misma formación.

En breve tiempo, esta idea estrictamente solidaria de la identificación del estudiante con el cliente quedó destrozada bajo una triple evidencia: primero, la educación es un derecho social; segundo, la educación pública no puede implicar costo alguno para quien accede a ella, sino que tiene que ser financiada por el Estado como su responsable; y tercero, es imprescindible asegurar la calidad de la formación que se entrega, terminando con la desregulación del "mercado de la educación”. El sentido común coincidió, en definitiva, con la demanda: "educación pública, gratuita y de calidad": en un país donde todo es bien de consumo a buen precio de mercado, hasta lo más elemental, por cierto que hubo de coincidir con la gratuidad.

Pero "evade" toca los dos nervios más sensibles de todo el sistema: la corrupción y la colusión, con base en la idea de que los privilegios se alcanzan por medio de conductas delictivas o, al menos, éticamente impresentables. La acumulación de groseras evidencias connivencias ilegales entre empresas para gravar el precio de cosas tan elementales como el papel higiénico y, por cierto, los remedios; el financiamiento de campañas electorales por grandes capitales con el correspondiente cobro de favores; el robo a mano armada (habría que decirlo así) de recursos fiscales por parte de la alta oficialidad de las fuerzas armadas y policiales- se sumó a los casos de abuso y violación en la iglesia católica para debilitar del todo la confianza de la población en las instituciones fundamentales del país, precisamente, en un país donde esa misma confianza hace parte de la identidad de la población. Figura paradigmática de tales conductas, el presidente de la república. Como dije antes, a diferencia de los nombres de que se componía la divisa fundamental de las movilizaciones del año 2011 , "evade" no se limita a designar una acción, sino que la realiza, es un performativo, curioso, ciertamente, porque combina imperativo e invitación. Dice: tú tienes la iniciativa, no tienes necesidad de esperar a que haya una respuesta de alguien a quien interpelas ni necesitas que nadie satisfaga tu demanda, nadie más que tú mismo. Por otra parte, tiene una cara reveladora: “evade”, así funciona el país, a punta de evasión, toma tú la acción en tus manos, con tu cuerpo, salta el torniquete para desmontar desde dentro ese mismo funcionamiento. En consecuencia, es al mismo tiempo una puesta en cuestión y una puesta entre paréntesis del agente que tendría la autoridad y los medios para satisfacer la demanda, para rechazarla 
o negociarla. Se podría hablar de una interrupción del principio de soberanía, en la medida en que éste se alce piramidalmente hasta su cúspide, donde toda decisión se concentra, particularmente en un régimen fuertemente presidencialista como el chileno. "Evade" tiene, en este sentido, el cariz de una devolución de la soberanía a quien la detenta primaria y sustantivamente, o como dice la constitución aún vigente, a quien la ejerce: el pueblo, una palabra, un nombre, un espectro que ni siquiera la constitución de la dictadura (y de su comedido amanuense, el abogado Jaime Guzmán) pudo borrar, y así se mantiene en su Artículo 5\%.

Pero, dado que "evade" juega a contrapelo del funcionamiento del sistema, lo invierte y, al invertirlo, lo disloca, la devolución tiene, como decía, el carácter de una interrupción radical de la soberanía ${ }^{3}$.

Probablemente porque el poder establecido barrunta la interrupción, no ya solo de su investida dignidad sino de la mera iniciativa, reacciona desmesuradamente y sin suficiente premeditación, o quizá con un plan concebido a medias. Decreta el estado de emergencia, envía a las fuerzas armadas a la calle, las que traen consigo un amago que evoca los tiempos de la dictadura. Sin embargo, la población desobedece. La represión policial se torna paroxística. Probablemente en todas partes es así, pero en Chile algo hace que la represión, la violencia de los agentes del Estado y la reiterada violación de los derechos humanos se simbolice en mutilaciones horrendas. En la dictadura fue el golpe, la quema y el corte, la tríada del castigo que ya se puede consultar en Platón (remito al Gorgias, a la disputa entre Sócrates y Polos ${ }^{4}$ ). En 2019 son los ojos, el destrozo de los ojos de los manifestantes por disparos de balines apuntados directamente al rostro por la fuerza policial. Cegar: uno podría detenerse a interpretar, a extraer consecuencias, a concebir las implicaciones simbólicas, a riesgo de convertir un hecho bruto y brutal en una metáfora. Se ha hecho. Me resisto a hacerlo.

La interrupción de la soberanía instituida -muchos observadores y opinantes comentan a la sazón, consternados, que en Chile se ha quebrantado el estado de derecho- no

\footnotetext{
${ }^{3}$ Imprescindible es considerar la temporalidad de esta interrupción, esencialmente distinta del tiempo de la soberanía, que siempre es, en pro de sí misma, una soberanía sobre el tiempo. El tiempo del "evade", que después se prolonga en el tiempo de la protesta, de la marcha, de la asamblea, es en principio inconmensurable con el tiempo de la soberanía.

${ }^{4}$ Platón, Gorgias (Santiago: Editorial Universitaria, 2015), 476b-e.
} 
deriva, sin embargo, en anarquía. En verdad, es, repito, una reivindicación en acto de ese principio por el soberano originario: el pueblo. No la "gente", no ciudadanía, no la multitud ni la masa (palabras que constriñen o que exageran). Hablaba del "pueblo" como de un espectro. Así puede llegar a (re)sentirlo el poder instituido, cuando lo que invoca ese nombre adquiere algún tipo de masividad corpórea y presencial. El pueblo, un espectro. (Entre paréntesis sea dicho que así también podría llegar a conjurarlo algún liderazgo carismático, lo que ha ocurrido tantas veces, o bien, entre nosotros, un líder sin carisma alguno, como ocurre con cierto personaje que, en su impertérrita y rubia circunspección, recuerda a los oficiales más rematados de las SS). En cualquier caso, es un Otro mayúsculo. La Primera Dama, Cecilia Morel, con sinceridad enternecedora, habló de "alienígenas" a propósito de las multitudes marchando o congregándose en plazas y sitios públicos. Con similar inocencia confidenció a una amiga: "tendremos que reducir nuestros privilegios y compartir con los demás". Ciertamente, es el modo en que una clase enclaustrada en esos mismos privilegios tiene por fuerza que ver a todas y todos aquellos que pululan fuera del claustro, "los demás" (que están demás); pero me interesa lo radicalmente ajeno-alienum- que puede ser el susodicho "pueblo" visto desde la atalaya del poder. Alegar, como hizo el Presidente a dos días de iniciado el "estallido", que se está "en guerra contra un enemigo poderoso e implacable" 5 , que, no obstante, es tan evasivo como indeterminado, o sugerir que ese "estallido" y su violencia es digitado desde el extranjero, son otras piezas ejemplares de esta miserable mitología. Que tiene, sí, su fondo de verdad: el alien llamado o sobrenombrado (poco importa) "pueblo" es ese enemigo poderoso e implacable.

Desde otro punto de vista, el mayor peligro que encierra esta palabra, "pueblo", este nombre o sobrenombre, es que se crea, se suponga o se afirme enfáticamente que designa algo sustancial y sustantivo, algo que posee densidad ontológica. El "pueblo", he dicho en algún otro lugar, es una ficción. Y ya sabemos cuál es la fuerza de una ficción, cuando se cree en ella sabiendo que es una ficción. Su fuerza es la fuerza de la potencia pura, de la potencia como potencia. Cuando hablaba de una reivindicación en acto -que, en sentido propio, no tiene un sujeto, porque ese presunto sujeto no es otro que la potencia del "pueblo" o el "pueblo" como potencia- me refería precisamente a esto: esa reivindicación ejercida en

\footnotetext{
${ }^{5}$ Así, en una alocución a todo el país la noche del domingo 20 de octubre; las palabras se volvieron como bumerán contra su irresponsable emisor. Al día siguiente, el jefe de las fuerzas militares en estado de emergencia señaló en televisión abierta que él no estaba en guerra con nadie y que era un hombre feliz.
} 
la calle masivamente es el acto de una potencia que toma cuerpo y se hace presente en el tiempo de ese mismo ejercicio. El tiempo es un dato esencial de esta potencia que, en ese acto, se afirma a sí misma como potencia en la diversa afluencia de quienes concurren y sostienen esa afirmación. Por eso, el acto de esta potencia como potencia tiene el carácter de una asamblea y el tiempo de una copresencia: el término viene del francés assembler, "reunir, juntar", que a su vez deriva del latín assimulare, que contiene simul, "a la vez, al mismo tiempo". Que es otro tiempo.

Me limito a consignar estos datos, antecedentes, elementos, no sé bien cómo llamarlos. No podría dar cuenta ni explicar cómo han confluido, bajo qué impulso, siendo tan diversos y hasta heteróclitos, cómo han llegado a coincidir. Me detengo aquí.

\section{Imagen}

Todo está registrado. Cada participante tiene un celular provisto de la capacidad para documentar y compartir todo lo que ocurre aquí, allá, en este o aquel otro momento, en el curso de tales o cuales situaciones e incidentes, lo que ha quedado estampado en los muros de la ciudad y en toda superficie apta para recibir la impronta de una figura, una consigna precisa o el rastro de una apresurada inscripción. Imágenes, lemas, palabras, cánticos y clamores, haces, fuegos y combates, escenas de dolor y de angustia, de júbilo, cuerpos y rostros ejerciendo el derecho a la presencia ${ }^{6}$. La manifestación y la marcha poseen la capacidad de autodocumentarse "en tiempo real", así como ha sido en los medios sociales que las convocatorias se han difundido: "La marcha más grande de Chile"7. La testificación de "lo que está ocurriendo" en el ahora de ese ocurrir, que inmediatamente queda disponible en la red como uno de miles de puntos de vista en la inmanencia de la manifestación, es un

\footnotetext{
${ }^{6}$ Imágenes: los exiguos apuntes iniciales a que me referí en la primera nota de este texto, como en intento de aprender a escribir de nuevo, estaban marcadas por un periodo de saturación de todo lo que circulaba y se difundía -noticias, comentarios, opiniones, análisis, pronósticos e interpretaciones, sobre todo estos tres últimos- acerca del "estallido". Necesité, un poco o muy a ciegas, distanciarme de todo lo que fuese discurso. Acudí a las imágenes. Habré pensado, sin saberlo: en las imágenes hay siempre una opacidad final, algo que se resiste al discurso y se resiste a la imagen misma; no es un punto ciego ni un punctum, quizá es solo un tránsito. Hablo de eso luego.

${ }^{7}$ La primera irrupción de los medios sociales en las movilizaciones en Chile sucedió en la antes mencionada "Revolución Pingüina": la toma de cientos de liceos y colegios a lo largo del país fue articulada y retroalimentada con ayuda de todos los medios disponibles en la época (2006), lo que imposibilitó toda capacidad de anticipación por parte de las autoridades.
} 
componente esencial de la forma contemporánea de reunión pública callejera. Eso hace de la imagen una pieza determinante de la autoconstitución transitoria de un colectivo popular ${ }^{8}$. Pero la pregunta es: ¿cómo funciona, cómo opera la imagen?

La circulación de las imágenes a través de la red, con todo lo que la acompaña emojis, opiniones, comentarios, exabruptos, lo que se quiera- y con las alteraciones que pudieren serle infligidas, ocurre idealmente (o si se prefiere, lo que en este caso es lo mismo, imaginariamente) en un plano horizontal que no conoce más límite que el cúmulo de likes o de repudios, de reacciones de toda laya que suscite, de reproducciones y reenvíos, sin perjuicio de que al cabo de un tiempo (que puede ser mucho tiempo) alguien resucite la pieza en cuestión, que en su calidad visual o sus signos contextuales puede delatar su anciana procedencia. Esta horizontalidad mediática confirma o refleja -o ambas cosas a la vez- la horizontalidad contrajerárquica, si puedo decirlo así, que es característica de las movilizaciones en curso.

Hay, a la vez, una suerte de anarquía y de inmanencia en la multiplicación de las imágenes. Esa anarquía y esa inmanencia remiten al modo de constitución de la multitudinaria asamblea callejera. Entre ambas, multiplicada circulación de las imágenes y congregación de los cuerpos en protesta, subsiste una relación inherente. Volveré sobre esto.

Salta a la vista la incorporación de códigos del cómic traducidos, a su vez, a la retórica del cine de héroes y vengadores, retórica de cine hollywoodense, pero sin su cosmética ni su cuidada coreografía. Surgen los iconos: el Pareman, el Nalcaman, la Baila Pikachu, La Señora de Morado y, por supuesto, el Negro Matapacos, legendario perro callejero de las movilizaciones estudiantiles de 2011, inmortalizado con pañuelo rojo amarrado al cogote, convertido en el perro primordial de Chile (junto a Washington, el quiltro de Condorito, probablemente...). Y estos mismos personajes dan lugar, a su vez, o sugieren nuevos cómics. Las imágenes gloriosas de "la primera línea" enseñan las poses, los gestos y las gestas de la gran épica cinematográfica, pero al mismo tiempo hacen presente su estricta vulnerabilidad, la precariedad de su equipamiento, la ausencia de todo poder especial que no fuese la del mero cuerpo expuesto y dispuesto al combate.

\footnotetext{
${ }^{8}$ Lo que supone también una diversidad de modos de ejercer lo que llamo "derecho a la presencia"; esta puede adoptar diversas modalidades: corpórea, verbal, medial, delegada, simbólica.
} 
La retórica en cuestión reproduce, a su vez, coreografías más antiguas, pictóricas y estatuarias. Y mantiene al monumento ecuestre de un general de la república convertido en la percha de un millón de afectos.

No puedo negar cuánto ha cambiado mi percepción y mi opinión de aquellas y aquellos a quienes se llama encapuchados. En muchas ocasiones expresé mi rechazo, mi sospecha, mi irritación. Tuve conocimiento cercano de acciones que consideré repudiables desde todo punto de vista. Escuché versiones de hechos que sugerían la infiltración en esos grupos de agentes policiales; me parecieron obvias. Me irritaba que su visible organización no se ocupara en fines propiamente políticos, con capacidad estratégica y de adhesión y convocatoria. Pero la "primera línea", los múltiples testimonios, observaciones, comentarios, la eficiente acción expuesta, con poco resguardo y apoyo convencido, la multiplicación de las capuchas, me cambiaron. No firmo nada en blanco, pero estas y estos "capuchas" están allí, combaten allí por lo que importa, lo que allí mismo importa a todas, a todos. Y allí mismo nace el desconcierto, la calle ciega en la que se encuentra la izquierda por doquier. Es calle ciega, otra que la calle en que se aglutinan los manifestantes, calle que no dejaré de decir que es el domicilio del pueblo. A condición, sí, como insinuaba, que se entienda que el pueblo es una ficción, un espectro, un fantasma que lo recorre todo, que está en todas partes y en ninguna y que, por eso mismo, es la aparición (la aparecida) en que se clava nuestra esperanza, nuestra fe, nuestro deseo: deseo de la constitución de la comunidad en y desde su inmanencia.

Pero ¿qué es lo (se) imagina (en) la imagen? ¿Qué hace la imagen consigo misma, de sí misma? No es lo mismo que preguntar de qué es imagen la imagen, aunque esta pregunta jamás puede ser suprimida de plano: es indisociable del estatuto de la imagen. No es lo mismo, digo, porque en este caso (y quizá en todos) se trata de la circulación de las imágenes, de su movimiento, del paso de una a otra y otra, y también del devenir imagen de la imagen; lo último implica que el paso de una imagen a otra también se da, como paso, en una misma imagen: dicho de otro modo, toda imagen es un paso, no se agota en sí misma ni es nunca plena, sino que su propia entidad, sin perjuicio de enfoque, encuadre y foco, abre y remite a otras imágenes, ilimitadamente. Esto es la medialidad de la imagen: toda imagen es medio de otra imagen, pero lo que decide esta medialidad en la imagen misma es el paso, el tránsito de una a otra y de una imagen a sí misma, en su devenir imagen: y ese paso, ese tránsito no 
es una imagen (o bien es todas las imágenes posibles, su aleph si se quiere, que es lo mismo), no es una imagen ni es imaginable.

Se trata de un punto tiene que ser establecido firmemente. Todo lo que acabo de decir, los giros y términos que he empleado, se entienden de suyo como referidos a facultades de un sujeto o capacidades de una psiquis. Si digo que toda imagen da paso a otra, que en una imagen están, si no contenidas, sí aludidas o sugeridas plétora de otras imágenes, de inmediato se piensa en flujos asociativos o mnémicos que tienen su residencia o lugar de ocurrencia en un sujeto o una mente. Si digo "imaginable" o "inimaginable" se asume que esa factibilidad o imposibilidad es algo que le sucede a alguien o que alguien puede llevar o no a cabo debido a una dotación, aptitud o competencia que le es propia. Imaginar es algo que alguien hace y que tiene su límite en el poder imaginativo que ese alguien tiene y, en general, en ese poder en cuanto presente en toda la comunidad a la que ese alguien pertenece y, en el extremo, si esa comunidad es la humanidad, todos los sujetos finitos, la congregación de todos los espíritus. No lo entiendo así. Si digo "imaginable" o "inimaginable", hablo del devenir imagen de la imagen como algo que es inherente a esta, con prescindencia de sujetos o mentes en que ese devenir acontezca o de los cuales ese devenir dependa. Este es el sentido que tiene la idea de que el paso, el tránsito de una imagen a otra y de una imagen a sí misma (en su devenir imagen) no es una imagen ni es imaginable.

En el terror platónico ante la mala mimesis -es decir, la del retórico, el pintor, el cosmetólogo, el fabricante de golosinas, pero sobre todo eminente entre la "tribu de los imitadores", el poeta- hay alojado un saber esencial acerca de esto, acerca de una suerte de autonomía (y hasta de autocracia) de la imagen. Que interrumpe la soberanía. El pintor y el poeta tienen la rara aptitud de independizar la imagen de la cosa de la cosa misma, darle una anómala subsistencia ontológica y, desde esta, convertirla en principio desde el cual juzgar y acaso producir equívocamente- esa cosa, ya nunca más la misma ni tampoco evocadora de su mismidad ideal, como aquello que produce el artesano. Doblándolo, desdoblan lo real, que ya se torna irrecuperable en su doble: apariencia, fantasma, eidolon, simulacro. Pero pintor y poeta han sido precedidos desde siempre por esa agencia primigenia que, incluso, le ha sugerido al artesano los modelos o evocaciones de su producción: es la physis, la fuente, raíz, lugar y fuerza de todo surgir. ¿Acaso no se reflejan árboles y follaje en el espejo de las aguas, acaso no echa sombra el animal que acecha o aquel que barrunta el peligro, tembloroso, acaso 
no dejan ambos sus huellas en la vertiginosa escena de la caza, acaso no resuenan los ecos de las miríadas de voces y crujidos, chasquidos y rumores en el bosque? El desdoblamiento ya ocurrió y persiste, impenitente. La imagen es su criatura, es su causa. Aterra solo pensar que hay reflejos, sombras, huellas, ecos, que se multiplican interminablemente en ausencia del testigo humano. ¿O no es así? ¿No se requiere siempre que haya alguien que percibe, para quien existe la sombra, el eco, la huella, el reflejo? ¿Habrá espejismo sin nadie que lo perciba? (La pregunta no es inocua para el país donde nada pasa(ba), definido como oasis rodeado de desierto o conflagración. Pero, claro, el oasis era un espejismo.) ¿No ocurre acaso todo esto en la percepción? ¿No se define por ella lo ilusorio? Pero entonces la percepción tiene una rara condición: no solo la posee quien la tiene y a quien afecta, también la reclama lo exterior. Ella es un entremedio. Es el medio por el cual la naturaleza -sigo apelando a este nombre, podría decir, acaso, lo "real"-, el medio en el cual (me corrijo) la naturaleza se relaciona consigo misma. La percepción es suya, también. Así que eco y reflejo, sombra y huella y espejismo pertenecen, como en diferendo o litigio, a quien percibe y a aquello en lo cual y desde lo cual lo percibido surge, emerge, se presenta, esté allí o no. La physis, ay, se desdobla, es ella y su doble y ya se sabe que el doble siempre es más que dos: un tercero (y acaso un cuarto) espectral le pena. Y la percepción es, en sí misma, precisamente porque no tiene mismidad en que reposar o refugiarse, es transmedial. No es, primariamente, la percepción de un sujeto. La percepción, de hecho, es anterior a todo sujeto.

La cuestión es cómo se piense ese trans. Trato de sugerir lo que alcanzo a ver: por eso insisto en aquella suerte de autonomía de la imagen -en virtud de la cual ella misma es heterónoma, se presta para cualquier uso y servicio, pero en perfecta indiferencia, celando su secreto-; insisto en la determinación doble de la percepción, siempre reclamada por lo percibido y el desde dónde de lo percibido; insisto en el flujo -que en ambas atestigua la huella, la estela, la sombra, la inquieta reverberación-; insisto en ese flujo. En castellano llamamos al lugar, espacio o tiempo, espacio $y$ tiempo en que tal flujo ocurre y que, en esa medida, agrego, lo hace posible, "entremedio"; hace un momento evocaba la expresión. Según nuestro diccionario estándar, el de la Real Academia Española, esta voz significa "lo que está en medio de los extremos". Sin embargo, siguiendo esta definición, "entre" y "medio", juntos, parecen redundantes; se diría también, alternativamente "lo que está entre los extremos" sin que la definición sufra mayor merma. La redundancia es, acaso, la inquieta 
reverberación. Pero es una redundancia productiva. "Entremedio", no lo que está entremedio, sino este mismo lugar, que es un lugar paradójico donde nada está ni puede estar, que es en este sentido un no-lugar, ou-topos, porque el paso y el flujo, a la vez que lo confirman (pues sin él no los hay), lo borran, lo consumen, si puede decirse así. "Entremedio" es aquello indesignable que facilita el flujo y a la vez hace posible a los extremos. Todo trans y todo extremo (posición, cosa, intensidad, sujeto) se deben a él. No es nada y es todo el lugar, o bien es el lugar crítico por excelencia, el no-lugar desde el cual se define el espacio público (y el tiempo público): la dispersión de la asamblea en que se empeña por todos los medios la fuerza policial señaliza, precisamente, lo crítico de ese lugar, usurpándolo, cancelándolo, negándolo. Un NO mayúsculo, a la fuerza, quiere celarlo, y lo guarda, y lo cierra. Otro NO (no un sí), otro $N \Theta$, un tercero (o cuarto), al margen de todo SÍ y de todo NO, lo conjura, lo abre. La multitud se reagrupa.

Vuelvo a las imágenes. De ellas, por cierto, hay diversas formas de lectura. Podemos verlas como fragmentos, retazos, encuadres fugaces, instantáneas (aun si son videos), y quizá quedarnos en un deambular como de galería, observando con mayor o menor atención cada imagen. Podemos, acaso, hacer el intento de extrapolar desde ellas el contexto general en que cada una se inscribe, lo que sin duda es vano, no solo porque cada una es un fragmento, sino porque es un momento, es decir, un momentum, la instancia de una aceleración que es inconmensurable con cualquier otra, si bien todas son solidarias en un acontecimiento del cual son astillas y que es imposible de reconstituir a partir de lo que observamos, porque no sabemos la ley de su relación: es, precisamente, la ley que falta, la forma de la ley que al mismo tiempo se anuncia y se sustrae en cada imagen. En ese anuncio y sustracción está la promesa de una totalidad. Pero es radicalmente diferente a aquella que el Espíritu que rememora íntimamente -que recuerda, er-innert- asume y apropia, sin sustracción o con sustracción que siempre se apropia, que se recupera en un estado más alto, en su lento paso por la galería de todas sus figuras: hablo de Hegel, por cierto, evoco el magnifico párrafo final de la Fenomenología del espíritu ${ }^{9}$. La totalidad que en este caso se anuncia y sustrae, a pesar de todas las apariencias y de todos los ímpetus, no es un telos, no es consumación ni su amago o su contrahechura, siempre atroz: la totalidad está allí mismo, fugitiva a cada

\footnotetext{
${ }^{9}$ Ver G. W. F. Hegel, Fenomenología del Espiritu (Ciudad de México: Editorial Fondo de Cultura Económica, 2017).
} 
momento, en cada momentum; es promesa, sí, pero promesa que se cumple (sin consumarse) en ese momentum, indecisa, improbable, imposible, pero siempre posible en su misma imposibilidad, es decir, inminente. La inminencia es el tiempo de la promesa ${ }^{10}$.

Hay, quizá, distintos nombres para esa totalidad. Si se piensa en las manifestaciones multitudinarias, en los gestos y cantos, las improvisadas coreografías, la efusión de las voces y los afectos, la evidencia de los cuerpos, en las múltiples escaramuzas con la fuerza policial, a la movilización en Chile la caracteriza la total ausencia de emblemas partidarios. Banderas chilenas y mapuche han sido los emblemas, los únicos emblemas enarbolados en las manifestaciones. Banderas chilenas, algunas negras con la estrella blanca, que son de lectura múltiple, colores simbólicos de clubes de fútbol enarbolados por las "barras bravas", pero no en discordia unas con otras, sino solidarias. Banderas que no expresan una pertenencia, sino un deseo, una aspiración e -insisto en la palabra- una promesa. Ello hace de la reunión multitudinaria algo muy distinto a la declaración de una positiva procedencia o raigambre. No venimos de ninguna parte, nuestro origen está borroneado y, acaso, mutilado, somos bastardas y bastardos, solo podemos (solo queremos) ser hijas e hijos del "pueblo", madre primordial que nunca estuvo, padre que no fue. Precisamente el hecho de que no haya contenidos sustantivos que la muchedumbre congregada reivindique o postule es lo que permite entenderla como "pueblo" y concebirla como portadora de una promesa que se sostiene exclusivamente sobre su propia performance: "Hasta que valga la pena vivir", "Hasta que la dignidad se haga costumbre". "Hasta": el tiempo enarbolado de la promesa.

¿Qué promesa es la que se formula y se compromete en las frases que vocea el conjunto de esos cuerpos, afectos y existencias volcados a la calle? ¿Qué promesa se sella en nombre del "pueblo"? ¿Qué promesa circula y toma cuerpo en todas y todos ellos como "pueblo"? El "pueblo", ese que hoy ocupa las calles y las plazas en mayor o menor número en afirmación y testimonio de sí, es la promesa de un "común” allí donde este puede llegar a ser o es llanamente insostenible, imposible. Es una promesa comunista en un sentido que sigue pendiente, que siempre sigue pendiente.

\footnotetext{
${ }^{10}$ Es el tiempo - y la temporalidad de tal tiempo- que sería necesario pensar en conjunto con el tiempo de la interrupción de la soberanía. Sí, querida María del Rosario Acosta, la deuda de este texto - la mayor, quiero decir- es la que tú me indicaste: tiempo de la interrupción, tiempo de la promesa, cómo son el mismo y nunca el mismo, sino siempre otro tiempo.
} 
Canta la muchedumbre o quizá un pequeño grupo, o alguien en una esquina o en una plaza: "El pueblo unido". "El pueblo unido" habla del espectro, lo dice, dice la insistencia espectral del "pueblo" y es dicho por este mismo. Espectral, no trascendental. No es la unidad del pueblo como ideal regulativo, hipótesis necesaria o postulado sin el cual soberanía, gobierno y autoridad serían impensables o inconsistentes. El "pueblo" es inmanente, es de esta tierra y experiencia, es el límite de toda experiencia común a que pudiésemos aspirar y la frontera siempre abierta de la tierra, sin muros ni vallados. Es, insisto, una promesa. “Jamás”, "jamás será vencido" mide la magnitud de esa promesa.

Pero las imágenes -lo que intento pensar como el paso, el movimiento, el momentum de la imagen y las imágenes, el trans y el entremedio-, las imágenes de la marcha, de la asamblea, de la manifestación y la protesta multitudinaria, de las múltiples escaramuzas con las fuerzas represivas, no son solo imágenes-de, a manera de inventario visual archivable como registro o testimonio. En su juego de cruces y cruzas, de parciales, locales -y a la vez abiertas- referencias de unas a otras, estas imágenes evidencian lo que antes llamé el modo de la asamblea callejera. También a ella la define el paso, el trans y el entremedio. Lo que importa en ella no es la aglomeración, no es masa compacta: lo que importa es el espacio, a veces mínimo, que hay entre un cuerpo y otro, entre una y otra pasión: porque ese es el espacio (y el tiempo) del encuentro, la mera posibilidad de un común allí donde nada común pudiese haber ${ }^{11}$. Esa es la promesa, esa es la potencia.

\section{Violencia}

\footnotetext{
${ }^{11}$ Evoco aquí la observación de Judith Butler: la performance de los cuerpos en acción de aparecer, configurando espacio público donde este, de un modo u otro, permanecía secuestrado, ocurre en un "entre" (between): "la acción emerge del 'entre', figura espacial de una relación que a la vez vincula y diferencia". Judith Butler, Notes Toward a Performative Theory of Assembly (Cambridge MA: Harvard University Press, 2018), 77. Este "entre", "entremedio", sugiere algo fundamentalmente distinto a la "masa" de Elias Canetti: no responde al miedo de ser tocado - "Nada teme más el ser humano que ser tocado por lo desconocido", señala Elias Canetti, Masse und Macht (Frankfort del Meno: Fischer, 2013), 13 [hay edición en castellano: Masa y poder. Horst Vogel trad. (Barcelona: Muchnik Editores, 1981]-; ni a la inversión ominosa que constituye a la masa -"Es la masa únicamente en la que el ser humano puede ser redimido de este toque. Es la única situación en que ese miedo se convierte en su contrario", ibid., 14-. Por cierto, la masa a la que se refiere Canetti ostenta todas las señas de la multitud fascista; aquí intento pensar la muchedumbre que se reúne en nombre de la justicia y cuyo horizonte político no puede sino ser la radicalización de la democracia.
} 
Todo está registrado. Los enfrentamientos, las luchas callejeras, la profusión de incendios (muchos de ellos de dudoso origen), el destrozo selectivo de inmuebles, el pillaje y los saqueos, la asolación en las poblaciones, la represión extrema de las fuerzas policiales, los cuerpos ensangrentados, las mutilaciones. Si no registradas, están documentadas, cuantificadas, acusadas judicialmente las desnudeces humillantes, las torturas, las violaciones.

La palabra genérica, por cierto, es violencia.

Hablaba del tiempo de la promesa. Es el tiempo más exigente, porque es tiempo que abre el tiempo más allá de su clausura en un presente dado que los beneficiarios de este quieren perpetuar. Ese tiempo no se da sin más, no viene ni pulsa gratis. Aquellos beneficiarios suelen llamar "violencia" a todo acto y empeño que busque el quiebre de la clausura. Y, entonces, pareciera ser que el tiempo de la promesa-es decir, el tiempo en que actúan quienes se esfuerzan por mantenerla- es indefectiblemente el tiempo de la violencia. Y a menudo lo es, ahí donde la violencia es padecida y ejercida, ejercida porque padecida, y vuelta a padecer porque ejercida. Pero una y otra no son la misma violencia o, dicho de otro modo, quizá más preciso, no pueden ser nombradas del mismo modo.

¿Es preciso hablar de violencia? Es absolutamente necesario, no cabe esquive ni subterfugio. Por doquier y en boca de casi toda persona que se ve llevada a pronunciarse al respecto se escucha (hablo de Chile): "condeno la violencia", "condeno la violencia en todas sus formas", "condeno la violencia venga de donde venga". Son expresiones rápidas, indeliberadas, automáticas, como si fuesen dictadas por una imposición irrebatible, que solo haciéndose censurable o culpable se podría desobedecer. Si no la condenas, entonces la avalas (en sordina: si dices "comprender" la violencia en que incurren grupos e individuos, quizá marginados sociales, pero no adhieres a ella, ¿por qué antepones esa comprensión y no la explícita condena? ¿Por qué te demoras en decir que no la justificas?). Se exige, pues, la condena de la violencia. Desde luego, este requerimiento - esta imposición que no admite réplica- lo formula hoy por hoy sobre todo un gobierno y una derecha exasperada, interesada en arrinconar a sus adversarios políticos, empujarlos al rincón opuesto a aquel en que ella misma se encuentra. Y gran parte de esos adversarios, algunos, acaso, con un dejo de desasosiego o de mero aturdimiento, ceden a la exigencia, a la imposición. (Muchos son partícipes de la condena sin matices, como una suerte de reflejo condicionado.) La figura es 
patética y a la vez peligrosa y es, considerada a mínima distancia, escandalosa, como lo es la imposición de obedecer. Pues bien: es preciso desobedecerla. De otro modo se puede caer en confusiones y errores que tienen consecuencias; hay prueba de ello. Y esa misma imposición es violenta. En este tiempo, en Chile, ha prevalecido un discurso dominante que se resume en aquellas frases y que es impulsado por un gobierno que pone las medidas policiales y represivas (so capa de "orden público") por sobre las demandas y necesidades sociales y que es acatado en la pauta de los medios y de manera no menor en el parlamento. Mezclándolo todo, manifestación y saqueo, protesta, vandalismo y pillaje, delito y reivindicación, se busca obnubilar la evidencia del abuso, la exclusión, la marginación y el arrinconamiento en condiciones de vida al borde de lo posible que el sistema que nos rige reanuda día a día, y que no es violencia ocasional sino constante; y oblicuamente, se legitima violaciones a los derechos humanos y crímenes de lesa humanidad perpetrados por agentes de Estado con anuencia de las más altas autoridades, con una autonomía que quebranta de manera flagrante, aquí sí, el estado de derecho. Si es preciso hablar de "violencia", un mínimo discernimiento es imperativo.

De manera que me interesa detenerme en lo que está en juego, de fondo, en ese requerimiento de condena. ¿Qué dice este requerimiento, esta imposición? Dice llanamente: ¡no pienses! ¡Aquí no hay espacio para la duda, el reparo, el discernimiento, la consideración y el análisis: condena! “¡No pienses!” Ese es un tipo particularmente capcioso y virulento de violencia, que se disfraza de repulsa y avala, por su cuenta y como su mera extensión, las peores medidas de represión, hasta el horror y el asesinato en que puedan incurrir los organismos a los que se ha concedido, aunque bajo condiciones que aquí simplemente se omiten, el monopolio de la fuerza. “¡No pienses!”: si con eso se quisiera decir -sin quererlo, desde luego, por error, omisión o equívoco- que la violencia es impensable, eso ya es un comienzo, a partir de eso ya se puede, ya se podría empezar a conversar.

La violencia, un impensable. ¿En qué contexto? Obviamente, no en todo contexto posible. De hecho, la mayoría de los contextos históricos, políticos y sociales han dispuesto formas y prácticas de violencia sancionada, instituida, ritualizada, algunas de las cuales persisten hoy en entornos culturales de diversa índole: formas y prácticas que no se consideraron "violentas", así como las que hoy persisten se consideran tales en el sentido que espontáneamente (bajo el peso de la imposición) atribuimos al término: aplicación de fuerza 
con propósito o resultado de daño, destrucción, coerción. Es en el contexto de la democracia donde cabría sostener que la violencia es impensable. No porque no pueda darse en ella, y de hecho se dé continuamente, sino porque, aparentemente, democracia y violencia, en idea, se excluyen mutuamente. La democracia, idealmente, establecería las condiciones para resolver todos los conflictos y todas las disputas por medios no violentos y tendría, por ello mismo, en su concepto y su principio, una relación esencialmente alérgica con la violencia.

Pero las democracias no son necesariamente su concepto ni su principio. La violencia tiene lugar en ellas no solo como amenaza o atentado contra la estabilidad o régimen de la democracia, ni únicamente como uso legítimo de la fuerza para proteger una u otro, sino también como regla cotidiana de existencia: de ciertas existencias. Allí donde la forma democrática reviste relaciones capitalistas, la violencia regula la existencia. El capitalismo es violencia.

Tiene sentido preguntarse por lo que pasa entre -entremedio de- violencia y democracia, la democracia de la que se hace tan expedita o escuetamente profesión de fe sin mayores especificaciones (sabemos quiénes no irán mucho más allá de "estado de derecho" y "orden público") y la violencia de la que esos mismos dicen que rompe y quebranta y finalmente destruye la democracia de la que hablan (y solo hablan). Tiene sentido que nos preguntemos por la relación entre violencia y democracia. Porque la democracia de la que aquellos hablan se sostiene sobre la violencia, una violencia sorda y constante, que si es contestada -con lo que llaman (también genéricamente) "vandalismo", aunque eso pueda designar solo el ejercicio del derecho a reunirse y protestar y a resistir la represióninmediatamente dispara la protesta de rigor, la condena de esa violencia. Pero es esa violencia, esa otra que estalla la que hace audible y visible la violencia sorda sobre la que descansa, y de la que se nutre día a día lo que aquellos llaman "democracia" ${ }^{12}$. Reitero: el capitalismo -vístase o no de "democracia"-es violencia.

¿Qué "violencia" es la otra violencia? Desde el primer día de la odiosa alocución de Piñera ("Estamos en guerra"), se respondió en todas las manifestaciones "No estamos en

\footnotetext{
${ }^{12}$ Lo que dije acerca de la "primera línea" me habrá hecho inmediatamente reo de lo que se suele llamar una "apología de la violencia". Los denunciantes de esta presunta "apología" tienen en la mira tres tipos paradigmáticos de "violentistas", según se les llama genéricamente: el terrorista, el vándalo, el delincuente. Dado que en el presente caso la tipificación de "terrorista" no tiene asidero, son las otras dos las que se aplica, más o menos indiscriminadamente: si el vándalo destruye por destruir, sin plan ni propósito, el delincuente tiene una finalidad precisa; ambos coinciden en atacar la propiedad.
} 
guerra". Los manifestantes y "la primera línea" insisten hoy: "No somos los violentos. Somos la resistencia". Y es preciso señalarlo: la violencia que eventualmente tiene lugar en las marchas y concentraciones opera sobre cosas (y las más de las veces de manera selectiva, como dije antes), la violencia represora del gobierno opera sobre personas. Nada de extraño tiene que, para el régimen imperante y su soporte político, económico y tendencialmente militarizado, las cosas -es decir, la propiedad privada y pública (que se trata como si fuese privada) - valgan tanto y más que las personas que se manifiestan y que ya son latentemente criminalizadas por el hecho de manifestarse.

$\mathrm{Y}$ es precisamente la manifestación -como quiera que ella se haga y se cumpla, pero ante todo, por cierto, en cuerpo presente- la que contiene, implícita, una referencia a la violencia. La contiene, particularmente, en todas aquellas y todos aquellos, y aquelles, que exigen no seguir siendo excluidos, no ser vulnerados y victimizados permanentemente para sostener un sistema que les cobra subsidio para el enriquecimiento de unos pocos, subsidio consistente en precariedad, vida, dignidad. Dignidad, sí, es la palabra en que convergen todos los afectos y pensamientos del estallido, "Dignidad", el nombre con que los manifestantes han rebautizado la Plaza Baquedano (o Plaza Italia), centro álgido de las concentraciones y de la declaración en cuerpo y acto de estar allí. ("No estoy ni ahí" era la frase consabida de la década de los noventa, refunfuñada sobre todo por una juventud marginada y discriminada, que no veía otro horizonte para sus vidas que el eriazo en que permanecía obligada a deambular; hoy la frase es “Con todo, si no pa' qué”.) Estar allí, decía, manifiestamente, ejerciendo el derecho a la presencia, a figurar en la presencia, a poner el cuerpo y resistir.

Hannah Arendt definió famosamente la violencia por su instrumentalidad, por su calidad de medio para la consecución de fines, en el interés expreso de disociarla esencialmente del poder ${ }^{13}$. Me inclino más a entender la violencia à la Benjamin, concibiéndola a partir de la medialidad del medio, como principio, con prescindencia de los

\footnotetext{
${ }^{13}$ En tanto que la violencia es instrumental y sus "implementos (...) están destinados y usados al propósito de multiplicar la fuerza natural", el "poder corresponde a la capacidad humana no meramente de actuar, sino de actuar de manera concertada". Hannah Arendt, On Violence (San Diego: Harcourt Brace \& Company, 1970), 46 y 44 respectivamente). Arendt escribe su libro en época de la apología de la violencia revolucionaria, solo puede pensar la violencia como medio que el fin, aparentemente, podría justificar. La sitúa del lado de la naturaleza y así, también, de un tipo de inmediatez que es propia de la fuerza como dote original, en tanto que el poder, que requiere de concertación y acuerdo, es originalmente racional, presupone el lenguaje y, asimismo, la institución.
} 
fines a los que su uso pudiera dirigirse ${ }^{14}$. Pero a la vez me interesa pensar lo que llamaba el momento manifestativo (que en Benjamin pertenece a la esfera del mito), como una suerte de vestíbulo, de umbral a partir del cual la violencia es posible.

Pero por cierto que aquí se juega la cuestión de la instrumentalidad, también.

Lo más peligroso de la movilización social en protesta y demanda es permitir que su resistencia quede capturada y subsumida bajo el genérico "violencia". Y eso, que es el estigma fundamental que el poder establecido quiere imprimirle indeleblemente a través de todos los medios de que dispone, incluidos el montaje y la mentira, también puede ocurrirle desde dentro, también puede haber acciones y agentes en el seno de la asamblea callejera que presten visos a la marca y el estigma, por distintas en su carácter y específicas que puedan ser.

El peligro en juego en esto es pasar de lleno a un estado de "democracia violenta", es decir, una que, en nombre de la seguridad como principio supremo, como aquello que ante todo la (supuesta) democracia debe proveer, restrinja acentuadamente derechos, extienda el repertorio de actos considerados delictivos, criminalice determinadas conductas y hasta modos de presencia pública (entre nosotros tenemos, flamantes, la "ley antisaqueos" y la "ley antiencapuchados", esta última que impone penas a quienes oculten su identidad de alguna manera en un contexto de desórdenes públicos) y, finalmente, que proporcione grados de inmunidad (es decir, de impunidad) a la acción de las fuerzas policiales. Y ese estado se está incubando.

¿Qué pasaría si el pensamiento de la democracia, si la afirmación y la defensa de la democracia, hoy, exigiese pensar radicalmente la violencia? ¿Qué pasaría si la violencia fuese inherente a la democracia, como tensión originaria e insuprimible, si bien acaso negociable, reducible? ¿Qué pasaría si la democracia no fuese sino el programa sostenido de una reducción de la violencia en todas sus formas? Y lo es, ciertamente, es parte sustantiva de su consabida definición. Pero ¿qué pasaría si por eso mismo tuviese necesariamente que haber una relación esencial y originaria entre democracia y violencia?

El horizonte de la democracia no es la reducción de la violencia, sino su traducción, precisamente en el momento a partir del cual ella es posible.

\footnotetext{
${ }^{14}$ Walter Benjamin, "Para una crítica de la violencia”, en Letal e incruenta, P. Oyarzun R., Carlos López P. y Federico Rodríguez eds. (Santiago: Lom ediciones, 2017), 19.
} 
El estallido ha hecho emerger, y este es acaso su hecho, su factum fundamental, ha hecho emerger un fondo primario, una brecha en la articulación social establecida, en el modo de ser ordenadas, reguladas y administradas las relaciones e inscripciones sociales. Ese vacío hace posible una rearticulación (imprevisible) de lo social por lo social mismo, por el "pueblo". Es un vacío y a la vez un suspenso, de hecho, una alteración del tiempo de lo social, de la normalidad temporal regulada por el trabajo y el consumo, que sugiere la inminencia de una temporalidad radicalmente distinta, cuyo índice, si puede decirse así, es la transitoriedad. El tiempo de la traducción.

En ese vacío y suspenso -en ese entremedio- prevalece el espectro llamado "pueblo", tanto como prevalece la posibilidad inherente, indeleble, de la violencia. Si el "pueblo" pudiese ser pensado como un sujeto (y no lo es, por su diversidad, su variación y apertura constitutivas), sería el sujeto (el punto de convergencia) de una traducción de la violencia en un sí a la alteridad y la extrañeza, a la extranjería primordial de todo lo humano y de todo lo otro-que-humano.

\section{Agradecimientos}

Este texto fue presentado en la conferencia principal del IV SoCrit Annual Meeting: Transmedial Latin America. University of Southern California, Los Angeles, Estados Unidos, el 20 de febrero de 2020, bajo el título "The Land Where Nothing Happens". La misma conferencia fue presentada en la University of California San Diego, La Jolla, 2 de marzo de 2020. Agradezco a mi querida amiga Erin Graff Zivin la invitación, su hospitalidad y la inteligencia de su trabajo. La presentación recoge parte de unas notas que, bajo el título común "El enigma de lo social", empecé a escribir precariamente en Madrid, a fines de noviembre de 2019, para uso meramente personal. No es improbable -pero tampoco existe certeza alguna- que, en el ánimo de pensar en todo el alcance posible lo que el "estallido social" en Chile ha abierto, la continuación de estas notas acabe por convertirse en un escrito mucho más extenso que el que aquí propongo. El preámbulo que antecede a las tres secciones del texto (y un par de frases más) reproduce parte de una breve contribución a Cristóbal Balbontín editor, Evadir. La filosofia piensa la revuelta de octubre de 2019 (Santiago: Editorial Libros del Amanecer, 2020). 


\section{Referencias bibliográficas}

Arendt, Hannah. On Violence. San Diego: Harcourt Brace \& Company, 1970.

Benjamin, Walter. "Para una crítica de la violencia". En Letal e incruenta, P. Oyarzun R., Carlos López P. y Federico Rodríguez eds. Santiago: Lom ediciones, 2017.

Butler, Judith. Notes Toward a Performative Theory of Assembly. Cambridge MA: Harvard University Press, 2018.

Canetti, Elias. Masse und Macht. Frankfort del Meno: Fischer, 2013.

Hegel, G. W. F. Fenomenología del Espíritu. Ciudad de México: Editorial Fondo de Cultura Económica, 2017.

Hobbes, Thomas. Leviatán. O la materia, forma y poder de una república eclesiástica y civil. Ciudad de México: Editorial Fondo de Cultura Económica, 2017.

Oyarzún, Pablo. "La fuerza de un acontecimiento". En Cristóbal Balbontín ed., Evadir. La filosofia piensa la revuelta de octubre de 2019. Santiago: Editorial Libros del Amanecer, 2020.

Platón. Gorgias. Santiago: Editorial Universitaria, 2015.

\section{Sobre el autor}

Pablo Oyarzún R. Profesor de Filosofía y Estética, director del Centro Interdisciplinario de Estudios en Filosofia, Artes y Humanidades de la Universidad de Chile, y Coordinador del Doctorado en Filosofía, Estética y Teoría del Arte de la misma institución (Santiago, Chile). Dirige el Seminario Central de Investigación del Instituto de Arte de la Pontificia Universidad Católica de Valparaíso. Su investigación gira en torno a la metafísica, ética y filosofía política, epistemología y filosofía del lenguaje, estética y teoría del arte y la literatura, filosofía de la historia, cultura, educación y política. Entre sus libros recientes se cuentan Una especie de espejo. Swift: cuatro ensayos y una nota (Santiago: Editorial Universitaria, 2014); Baudelaire: la modernidad y el destino del poema (Santiago: Ediciones Metales Pesados, 2016); Devaneo sobre la estupidez y otros textos (Viña del Mar: Mundana

Ediciones, 2018). y Doing Justice: Three Essays on Walter Benjamin (Cambridge: Polity Press, 2020). Previsiblemente en 2021 aparecerán sus trabajos Literature and Skepticism y 
Between Celan and Heidegger (Nueva York), Variaciones sobre lo siniestro (Medellín) y De la traducción (Santiago). También en 2021 aparecerán dos libros colectivos dedicados a su trabajo. Sus traducciones incluyen a Epicuro, Pseudo-Longino, Jonathan Swift, Immanuel Kant, Heinrich von Kleist, Charles Baudelaire, Franz Kafka, Walter Benjamin, Paul Celan. Ha sido profesor visitante y dictado conferencias en diversos países de las Américas y de Europa. Ha recibido premios y distinciones. Correo electrónico: oyarzun.pablo@gmail.com. 